\title{
HUBUNGAN ANTARA PERUBAHAN KADAR HS-CRP DENGAN FUNGSI KOGNITIF PADA STROKE ISKEMIK
}

\author{
ASSOCIATION BETWEEN ALTERED HS-CRP LEVELS AND COGNITIVE FUNCTION OF \\ ISCHEMIC STROKE PATIENTS
}

Betsi Sumanti, * Hexanto, * Widiastuti*

\begin{abstract}
Introduction: The incidence of cognitive impairment in acute ischemic stroke patients is increasing. The mechanism of the inflammatory effect, such as elevated hs-CRP level, a non-specific inflammatory marker sensitive to chronic inflammation due to hypoperfusion as well other vascular risk, is thought to have an effect on cognitive function.

Aims: To determine the relationship of cognitive function changes in acute phase of ischemic stroke with hs-CRP level changes on day 3 and day 7 after onset.

Methods: This was a cross sectional study of 31 first-timer ischemic stroke patients who met inclusion and exclusion criteria. The level of hs-CRP was checked on the 3rd day and 7th day after onset, while MoCA-Ina was assessed on the 7th day after onset. Cognitive disturbance was considered if MoCA $<26$. Analyses was done using SPSS 2.0

Results: The average onset of day $3 \mathrm{Hs}-C R P$ concentration was $0.66(0.12-16.67) \mathrm{mg} / \mathrm{dl}$ and the onset of day 7 was 5.455 (0.14-17.34)mg/dl. The mean change of hs-CRP level between 3 day and 7 day after onset was -0,16 (-3.32-4.95). There was a significant correlation between elevated hs-CRP levels on day 3 and day 7 after onset with cognitive function of acute ischemic stroke patients.
\end{abstract}

Discussion: There was a significant correlation between elevated hs-CRP levels on day 3 and day 7 after onset with cognitive function of acute ischemic stroke patients.

Keyword: Acute ischemic stroke, hs-CRP, MoCA-Ina scores

\section{ABSTRAK}

Pendahuluan: Insidens penurunan fungsi kognitif pada pasien stroke iskemik akut semakin meningkat. Hal ini diduga dipengaruhi oleh mekanisme efek inflamasi, meliputi peningkatan kadar high sensitive-C reactive protein (hs-CRP), salah satu penanda inflamasi non-spesifik yang sangat sensitif pada inflamasi kronis, akibat hipoperfusi maupun karena risiko vaskuler lainnya.

Tujuan: Mengetahui hubungan perubahan fungsi kognitif pasien stroke iskemik fase akut dengan perubahan kadar hs-CRP hari ke-3 dan hari ke-7 setelah awitan.

Metode: Studi potong lintang terhadap penderita stroke iskemik pertama kali yang memenuhi kriteria inklusi dan eksklusi. Dilakukan pemeriksaan kadar hs-CRP hari ke-3 dan hari ke-7 setelah awitan dan MoCA-Ina pada hari ke-7 setelah awitan. Fungsi kognitif dinyatakan terganggu jika MoCA-Ina <26. Analisis data menggunakan program SPSS 22.0.

Hasil: Didapatkan rerata kadar Hs-CRP hari ke-3 setelah awitan adalah 0,66 $(0,12-16,67) \mathrm{mg} / \mathrm{dl}$ dan hari ke-7 setelah awitan adalah 5,455 $(0,14-17,34) \mathrm{mg} / \mathrm{dl}$. Dengan rerata perubahan kadar hs-CRP awitan hari ke-3 dan awitan hari ke-7 adalah -0,16 (-3,32-4,95). Didapatkan hubungan yang bermakna antara perubahan kadar hs-CRP hari ke-3 setelah awitan dan hari ke-7 setelah awitan dengan fungsi kognitif pasien stroke iskemik akut.

Kesimpulan: Didapatkan hubungan yang bermakna antara peningkatan kadar hs-CRP pada hari ke-7 dan kadar hari ke-3 dengan fungsi kognitif pasien stroke iskemik akut.

Kata kunci: hs-CRP, MoCA-Ina, stroke iskemik akut

*Bagian/SMF Ilmu Penyakit Saraf FK Universitas Diponegoro/RSUP Dr. Kariadi, Semarang. Korespondensi: bets.sey@gmail.com.

\section{PENDAHULUAN}

Insidens penurunan fungsi kognitif pada pasien stroke iskemik akut semakin meningkat. Hal ini diduga dipengaruhi oleh mekanisme efek inflamasi. Inflamasi adalah salah satu mekanisme dasar dalam patogenesis terjadinya aterosklerosis dan komplikasinya. Demikian pula peradangan sistemik dapat menyebabkan gangguan fungsi endotel, yang telah dikaitkan dengan hiperintensitas substansia alba, demensia vaskular, dan penyakit Alzheimer. Penanda inflamasi sistemik yang noninfeksius juga terkait dengan gangguan aliran darah otak. Penelitian pada hewan menunjukkan disregulasi fokal dalam aliran serebrovaskular di daerah yang penting untuk memori, seperti hipokampus. Hal ini menunjukkan bahwa peradangan sistemik yang luas bisa menjadi 
penanda penyakit vaskular, tetapi bisa juga secara langsung memengaruhi kaskade amiloid. ${ }^{1}$

Di sisi lain, perubahan aterosklerosis pada sereberal, stroke, dan leukoaraiosis khususnya, dapat mengganggu integritas sirkuit frontal sub-kortikal sebagai penyebab gangguan kognitif dan depresi. Oleh karena itu, inflamasi menjadi faktor kontribusi yang penting pada kerusakan neural pascastroke serta terbentuknya plak amiloid terkait defisit gangguan kognitif dan demensia pada orang tua. Salah satu penanda inflamasi non-spesifik yang sangat sensitif pada inflamasi kronis adalah high sensitive-C reactive protein (hs-CRP). Penanda ini diketahui berkorelasi dengan lesi pada substantia alba dan "silent" infark yang bertanggung jawab untuk penurunan kognitif dan demensia.

High sensitive-C reactive protein diduga dapat menunjukkan kerusakan mikro struktural serebral jalur frontal, terkait kinerja fungsi kognitif dan fungsi eksekutif. Hs-CRP juga meningkatkan ekspresi faktor jaringan dalam monosit; opsonisasi lowdensity lipoprotein (LDL), merusak fungsi endotel, dan meregulasi ekspresi adhesi molekul endotel, sehingga langsung berpartisipasi dalam penyakit vaskuler. Respons pro-inflamasi dapat menyebabkan kerusakan saraf dan aterosklerosis serebral yang berakibat makro dan mikro-angiopati. ${ }^{2}$ Syafrita dkk membuktikan adanya hubungan yang bermakna antara tingginya kadar hs-CRP dengan gangguan kognitif pada stroke iskemik fase akut. ${ }^{3}$

Di Napoli dkk mendapatkan kadar hsCRP $>1,5 \mathrm{mg} / \mathrm{dL}$ pada pasien pascastroke setelah perawatan $12 \pm 5$ hari memiliki luaran buruk, yang menunjukkan semakin tinggi kadar hs-CRP maka semakin luas inflamasi yang terjadi pada kerusakan otak akibat iskemik. Kadar hs-CRP akan meningkat saat 24 jam awal awitan stroke lalu menurun pada 48-72 jam hingga hari ke 8-14 setelah awitan dengan kadar masih tetap di atas normal. Temuan ini mendukung penelitian sebelumnya dan konsisten dengan peningkatan CRP yang mencerminkan tingkat infark pada otak. Namun terdapat $26 \%$ pasien dengan kadar CRP normal pascastroke, yang berarti stroke iskemik itu sendiri tidak menginduksi respons fase akut inflamasi seluruhnya.
Pasien dengan tingkat CRP yang terus meningkat memiliki hasil yang lebih buruk, mendukung kemungkinan bahwa inflamasi berkontribusi terhadap cedera otak iskemik. Defisit neurologis awal mencerminkan cedera pada inti serta penumbra. Ketika terjadi perfusi kolateral, fungsi otak dapat dipulihkan dalam area penumbra. Namun lesi struktural yang terbentuk akan merekrut bagian penumbra iskemik menjadi infark. Kerusakan otak yang berlanjut seperti itu dapat menyebabkan defisit neurologis meningkat seiring dengan waktu, walaupun terkadang gejala cenderung membaik selama minggu pertama setelah stroke. Mekanisme yang dapat menyebabkan persistensi reaksi fase akut ini belum dapat dijelaskan. ${ }^{4}$

Penelitian ini dilakukan untuk mengetahui hubungan antara kemungkinan perubahan kadar hsCRP antara awitan hari ke-3 dan awitan hari ke-7 dengan penurunan fungsi kognitif pascastroke, yaitu pada hari ke-7. Syafrita dkk melakukan pemeriksaan kadar tersebut hanya 1 kali pada awitan dalam 72 jam dan fungsi kognitif setelah 3 bulan awitan. Oleh karena itu diharapkan penelitian ini dapat mengidentifikasi penurunan fungsi kognitif lebih dini, sehingga dapat dilakukan intervensi untuk mencegah penurunan fungsi kognitif yang lebih berat dan terjadinya demensia.

\section{METODE}

Desain penelitian adalah studi potong lintang secara kohort prospektif terhadap pasien stroke iskemik akut yang dirawat di Bangsal Rawat Inap RSUP dr. Kariadi, Semarang, pada Juni-Desember 2016. Diagnosis stroke iskemik akut ditentukan berdasarkan gejala klinis dan CT scan kepala nonkontras. Setelah dilakukan informed consent, dilakukan pengisian data demografi, riwayat penyakit, dan kebiasaan merokok. Skrining pemeriksaan gangguan kognitif menggunakan tes Short IQ Code dan skala depresi Hamilton. Dikatakan gangguan kognitif bila nilai tes $<26$ dari 30 dan depresi bila nilai $>6$ dari $24 .{ }^{5}$

Dilakukan pencatatan pemeriksaan laboratorium kadar hs-CRP hari ke-3 dan hari ke-7 setelah awitan, diikuti pemeriksaan fungsi kognitif dengan instrumen 
Tabel 1. Karakteristik Subjek Penelitian $(n=31)$

\begin{tabular}{|c|c|}
\hline Karakteristik & n (\%) \\
\hline \multicolumn{2}{|l|}{ Jenis Kelamin } \\
\hline - Laki-laki & $18(41,9 \%)$ \\
\hline - Perempuan & $13(58,1 \%)$ \\
\hline \multicolumn{2}{|l|}{ Usia } \\
\hline$\bullet \geq 65$ tahun & $11(35,5 \%)$ \\
\hline - $<65$ tahun & $20(64,5 \%)$ \\
\hline \multicolumn{2}{|l|}{ Kadar hsCRP_H3 } \\
\hline$\cdot \geq 0,5 \mathrm{mg} / \mathrm{dL}$ & $26(83,9 \%)$ \\
\hline$\bullet<0,5 \mathrm{mg} / \mathrm{dL}$ & $5(16,1 \%)$ \\
\hline \multicolumn{2}{|l|}{ Kadar hsCRP_H7 } \\
\hline$\bullet \geq 0,5 \mathrm{mg} / \mathrm{dl}$ & $23(83,9 \%)$ \\
\hline$\bullet<0,5 \mathrm{mg} / \mathrm{dl}$ & $5(16,1 \%)$ \\
\hline \multicolumn{2}{|l|}{ Perubahan Kadar hs-CRP } \\
\hline - Meningkat & $13(41,9 \%)$ \\
\hline - Menurun & $18(58,1 \%)$ \\
\hline \multicolumn{2}{|l|}{ Pemeriksaan Jantung } \\
\hline$\bullet \mathrm{LVH}$ & $15(54,8 \%)$ \\
\hline - NSR & $16(51,6 \%)$ \\
\hline \multicolumn{2}{|l|}{ Hipertensi } \\
\hline - Ya & $19(61,3 \%)$ \\
\hline - Tidak & $12(38,7 \%)$ \\
\hline \multicolumn{2}{|l|}{ Diabetes Melitus } \\
\hline - Ya & $9(29,0 \%)$ \\
\hline - Tidak & $22(71 \%)$ \\
\hline \multicolumn{2}{|l|}{ Dislipidemia } \\
\hline - Ya & $6(19,4 \%)$ \\
\hline - Tidak & $25(80,6 \%)$ \\
\hline \multicolumn{2}{|l|}{ Sisi Lesi } \\
\hline$\bullet$ Kiri & $9(29,1 \%)$ \\
\hline • Kanan & $22(70,9 \%)$ \\
\hline \multicolumn{2}{|l|}{ Lokasi Lesi } \\
\hline - Kortikal & $1(3,2 \%)$ \\
\hline - Subkortikal & $24(77,4 \%)$ \\
\hline - Campuran & $6(19,4 \%)$ \\
\hline \multicolumn{2}{|l|}{ Jumlah Lesi } \\
\hline - Multipel & $21(67,7 \%)$ \\
\hline - Tunggal & $10(32,3)$ \\
\hline \multicolumn{2}{|l|}{ Merokok } \\
\hline - Ya & $8(25,8 \%)$ \\
\hline - Tidak & $23(74,2 \%)$ \\
\hline \multicolumn{2}{|l|}{ Indeks Massa Tubuh } \\
\hline - Obesitas & $7(22,6 \%)$ \\
\hline - Overweight & $18(58,1 \%)$ \\
\hline - Normoweight & $6(19,4 \%)$ \\
\hline
\end{tabular}

LVH: left ventricle hypertrophy, NSR: normal sinus rhythm.
Tabel 2. Karakteristik Fungsi Kognitif Subjek Penelitian

\begin{tabular}{lc}
\hline \multicolumn{1}{c}{ Variabel } & n (\%) \\
\hline Fungsi Kognitif & \\
- Terganggu & $16(51,6 \%)$ \\
- Tidak terganggu & $15(48,4 \%)$ \\
Ranah Fungsi Kognitif & \\
Atensi & \\
- Terganggu & $15(48,4 \%)$ \\
- Tidak terganggu & $16(51,6 \%)$ \\
Bahasa & \\
- Terganggu & $11(35,5 \%)$ \\
- Tidak terganggu & $20(64,5 \%)$ \\
Memori & \\
- Terganggu & $16(51,6 \%)$ \\
- Tidak terganggu & $15(48,4 \%)$ \\
Fungsi Eksekutif & \\
- Terganggu & $20(64,5 \%)$ \\
- Tidak terganggu & $11(35,5 \%)$ \\
Visuospasial & $15(48,4 \%)$ \\
- Terganggu & \\
- Tidak terganggu &
\end{tabular}

MoCA-Ina pada hari ke-7 setelah awitan. Data diolah dengan program SPSS for Windows versi 22. Analisis data dilakukan dalam dua tahapan yaitu tahapan statistik deskriptif untuk menentukan karakteristik dasar subjek penelitian dan tahapan analitik. Analisis multivariat dilakukan untuk mencari variabel yang paling bermakna menggunakan regresi logistik bila ada variabel pada uji bivariat dengan nilai $\mathrm{p}<0,25$.

\section{HASIL}

Pada 31 subjek yang mengikuti penelitian ini (Tabel 1), terbanyak adalah laki-laki $(58,1 \%)$ dengan rerata usia $60,77 \pm 13,27$ tahun dan tingkat pendidikan terutama $<12$ tahun $(51,6 \%)$. Didapatkan kecendrungan penurunan kadar hs-CRP awitan hari ke-3 dan hari ke-7, yaitu -0,16 (-3,32-4,95). Mayoritas subjek memiliki riwayat hipertensi $(61,3 \%)$ dengan indeks massa tubuh (IMT) overweight $(58,1 \%)$. Berdasarkan pemeriksaan CT scan, lesi iskemik terbanyak di sisi kanan (70,9\%), subkortikal $(77,4 \%)$, dan multipel $(67,7 \%)$.

Berdasarkan MoCA-Ina (Tabel 2), ranah fungsi kognitif yang terganggu paling banyak berturut-turut 
adalah eksekutif(64,5\%), memori (51,6\%), atensi dan visuospasial $(48,4 \%)$, serta fungsi bahasa $(35,5 \%)$. Subjek laki-laki lebih banyak mengalami gangguan fungsi kognitif, juga pada usia $<65$ tahun $(56,3 \%)$, dan pendidikan $\geq 12$ tahun $(56,3 \%)$, walaupun tidak bermakna (Tabel 3).

Tabel 3. Hubungan antara Faktor Demografis dengan Gangguan Kognitif (n=31)

\begin{tabular}{|c|c|c|c|}
\hline \multirow[b]{2}{*}{ Faktor Demografi } & \multicolumn{2}{|c|}{ Gangguan Kognitif } & \multirow[b]{2}{*}{$\mathbf{p}$} \\
\hline & $\begin{array}{c}\text { Ya } \\
(n=16) \\
\text { n (\%) }\end{array}$ & $\begin{array}{c}\text { Tidak } \\
(n=15) \\
\text { n (\%) }\end{array}$ & \\
\hline \multicolumn{4}{|l|}{ Jenis Kelamin } \\
\hline - Laki-laki & $9(56,3 \%)$ & $9(60,0)$ & $0,833^{\epsilon}$ \\
\hline - Perempuan & $7(43,8 \%$ & $6(41,9 \%)$ & \\
\hline \multicolumn{4}{|l|}{ Usia } \\
\hline$\bullet \geq 65$ tahun & $7(43,8 \%)$ & $4(5,3 \%)$ & $0,320^{€}$ \\
\hline - $<65$ tahun & $9(56,3 \%)$ & $11(9,7 \%)$ & \\
\hline \multicolumn{4}{|l|}{$\begin{array}{l}\text { Tingkat } \\
\text { Pendidikan }\end{array}$} \\
\hline - $<12$ tahun & $7(43,8 \%)$ & $9(60 \%)$ & $0,366^{\epsilon}$ \\
\hline$\bullet \geq 12$ tahun & $9(56,3 \%)$ & $6(40,0 \%)$ & \\
\hline
\end{tabular}

${ }^{€}$ Pearson Chi-square; ${ }^{\circledR}$ Fisher exact test.

Tabel 4 menunjukkan hubungan yang bermakna antara perubahan kadar hs-CRP awitan hari ke-3 dan hari ke-7 dengan fungsi kognitif $(p<0,001)$, namun tidak terdapat hubungan yang bermakna antara faktor-faktor perancu dengan fungsi kognitif. Adapun variabel yang bersama-sama berpengaruh terhadap fungsi kognitif adalah dislipidemia dan perubahan kadar hs-CRP awitan hari ke-3 dan hari ke-7 (Tabel 5).

\section{PEMBAHASAN}

Rerata usia pada penelitian ini lebih rendah dibandingkan subjek penelitian Nys dkk terhadap subjek dengan gangguan kognitif pascastroke iskemik, yaitu rerata $65,2 \pm 13,5$ tahun. Demikian pula Wersching dkk pada individu sehat mendapatkan nilai tengah usia subjek yang mengalami gangguan fungsi kognitif adalah 69,7 (65-85) tahun. Terjadinya stroke iskemik mungkin menyebabkan gangguan kognitif muncul lebih dini. Penurunan aliran darah otak dan usia merupakan faktor untuk kerusakan otak dan
Tabel 4. Analisis Faktor-faktor Risiko terhadap Fungsi Kognitif

\begin{tabular}{|c|c|c|c|}
\hline \multirow{4}{*}{ Variabel } & \multicolumn{2}{|c|}{ Gangguan kognitif } & \multirow{4}{*}{$\mathbf{p}$} \\
\hline & Ya & Tidak & \\
\hline & $(\mathrm{n}=16)$ & $(n=15)$ & \\
\hline & n (\%) & n (\%) & \\
\hline \multicolumn{4}{|l|}{ Riwayat Klinis } \\
\hline \multicolumn{4}{|l|}{ Hipertensi } \\
\hline - Ya & $11(68,8 \%)$ & $8(53,3 \%)$ & $0,379^{€}$ \\
\hline - Tidak & $5(31,3 \%)$ & $7(46,7 \%)$ & \\
\hline \multicolumn{4}{|l|}{ Diabetes Melitus } \\
\hline - Ya & $5(31,3 \%)$ & $4(26,7 \%)$ & $1,000 \S$ \\
\hline - Tidak & $11(68,8 \%)$ & $11(73,3 \%)$ & \\
\hline \multicolumn{4}{|l|}{ Dislipidemia } \\
\hline - Ya & $5(31,3 \%)$ & $1(6,7 \%)$ & $0,172 \S$ \\
\hline - Tidak & $11(68,8 \%)$ & $14(93,3)$ & \\
\hline \multicolumn{4}{|c|}{ Karakteristik Infark } \\
\hline \multicolumn{4}{|l|}{ Sisi Lesi } \\
\hline - Kiri & $5(55,6 \%)$ & $4(44,4 \%)$ & $1,000^{\S}$ \\
\hline - Kanan & $11(50,0 \%)$ & $11(50,0 \%)$ & \\
\hline \multicolumn{4}{|l|}{ Lokasi Lesi } \\
\hline - Kortikal & $1(6,3 \%)$ & 0 & $0,616^{\epsilon}$ \\
\hline - Subkortikal & $12(75,0 \%)$ & $12(80 \%)$ & \\
\hline - Campuran & $3(3,15)$ & $3(20 \%)$ & \\
\hline \multicolumn{4}{|l|}{ Jumlah Lesi } \\
\hline - Multipel & $11(68,8 \%)$ & $10(66,7 \%)$ & $1,000^{\S}$ \\
\hline - Tunggal & $5(31,3 \%)$ & $5(33,3 \%)$ & \\
\hline \multicolumn{4}{|c|}{ Pemeriksaan Laboratorium } \\
\hline \multicolumn{4}{|c|}{ Kadar hs-CRP_H3 } \\
\hline$\bullet \geq 0,5 \mathrm{mg} / \mathrm{dl}$ & $13(81,3)$ & $13(86,7 \%)$ & $1,000^{\S}$ \\
\hline - $<0,5 \mathrm{mg} / \mathrm{dl}$ & $3(18,8 \%)$ & $2(2,4 \%)$ & \\
\hline \multicolumn{4}{|c|}{ Kadar hs-CRP_H7 } \\
\hline$\bullet \geq 0,5 \mathrm{mg} / \mathrm{dl}$ & $15(93,8 \%)$ & $11(73,3 \%)$ & $0,172^{\S}$ \\
\hline - $<0,5 \mathrm{mg} / \mathrm{dl}$ & $1(6,3 \%)$ & $4(26,7 \%)$ & \\
\hline \multicolumn{4}{|c|}{ Perubahan Kadar hs-CRP } \\
\hline - Naik & $12(75,0 \%)$ & $1(6,7 \%)$ & $0,000^{\mathrm{s}}$ \\
\hline - Turun & $4(25,0 \%)$ & $14(8,7 \%)$ & \\
\hline \multicolumn{4}{|l|}{ Gaya Hidup } \\
\hline \multicolumn{4}{|l|}{ Merokok } \\
\hline - Ya & $5(31,3 \%)$ & $3(20 \%)$ & $0,685^{\S}$ \\
\hline - Tidak & $11(68,8 \%)$ & $12(80 \%)$ & \\
\hline \multicolumn{4}{|c|}{ Indeks Massa Tubuh } \\
\hline - Obese & $5(31,3 \%)$ & $2(13,3 \%)$ & $0,965^{€}$ \\
\hline - Overweight & $8(50 \%)$ & $10(66,7)$ & \\
\hline - Normoweight & $3(18,8 \%)$ & $3(20 \%)$ & \\
\hline \multicolumn{4}{|c|}{ Gambaran Fisiologi Jantung } \\
\hline - LVH & $8(50 \%)$ & $7(46,7 \%)$ & $0,853^{\epsilon}$ \\
\hline - NSR & $8(50 \%)$ & $8(53,3 \%)$ & \\
\hline
\end{tabular}


Tabel 5. Analisis Regresi Logistik Faktor yang Memengaruhi Fungsi Kognitif (n=31)

\begin{tabular}{|c|c|c|c|c|c|}
\hline \multirow[b]{2}{*}{ Variabel } & \multicolumn{2}{|c|}{ Gangguan Kognitif $(n=31)$} & \multirow{2}{*}{$\begin{array}{c}\text { Univariat } \\
\mathbf{p}\end{array}$} & \multicolumn{2}{|c|}{ Multivariat } \\
\hline & $\begin{array}{c}\text { Ya } \\
(n=16)\end{array}$ & $\begin{array}{c}\text { Tidak } \\
(n=15)\end{array}$ & & $\mathbf{p}$ & RO (95\%IK) \\
\hline \multicolumn{6}{|l|}{ Demografik } \\
\hline - Jenis kelamin (laki-laki) & $9(56,3 \%)$ & $9(60,0 \%)$ & 0,833 & & \\
\hline - Usia (<65 tahun) & $9(56,3 \%)$ & $11(73,3 \%)$ & 0,320 & & \\
\hline - Pendidikan ( $\geq 12$ tahun) & $9(56,3 \%)$ & $6(40,0 \%)$ & 0,366 & & \\
\hline \multicolumn{6}{|l|}{ Faktor Risiko Vaskuler } \\
\hline - Hipertensi & $11(68,9 \%)$ & $8(53,3 \%)$ & 0,379 & & \\
\hline - Diabetes melitus & $5(31,3 \%)$ & $4(26,7 \%)$ & 1,000 & & \\
\hline - Dislipidemia & $5(31,3 \%)$ & $1(6,7 \%)$ & 0,172 & 0,245 & $5,306(0,318-88,395)$ \\
\hline Delta hs-CRP & $12(75,0 \%)$ & $1(6,7 \%)$ & 0,001 & 0,002 & $42,00(4,115-426,663)$ \\
\hline \multicolumn{6}{|l|}{ Gaya Hidup } \\
\hline - Merokok & $5(31,3 \%)$ & $3(20,0 \%)$ & 0,685 & & \\
\hline - Indeks massa tubuh & $14(87,5 \%)$ & $12(80,0 \%)$ & 0,654 & & \\
\hline \multicolumn{6}{|l|}{ Karakteristik Infark } \\
\hline - Sisi lesi kanan & $11(68,8 \%)$ & $11(73,3 \%)$ & 1,000 & & \\
\hline - Letak lesi subkortikal & $15(93,8 \%)$ & $15(100 \%)$ & 1,000 & & \\
\hline - Jumlah lesi multipel & $11(68,8 \%)$ & $10(67,7 \%)$ & 0,901 & & \\
\hline
\end{tabular}

LVH: left ventricle hypertrophy, NSR: normal sinus rhythm.

penurunan kognitif. Usia yang semakin tua disertai berbagai faktor patologis pada sistem saraf maupun faktor risiko vaskuler turut memengaruhi status fungsi kognitif. CRP dapat berkontribusi pada proses penuaan fungsi kogntitif yang tergantung pada sisi dan lokasi lesi, sehingga penuaan juga berhubungan langsung dengan peningkatan kadar inflamasi pada lokasi lesi. ${ }^{4}$

Penelitian ini tidak didapatkan hubungan yang bermakna antara jenis kelamin dengan fungsi kognitif, walaupun subjek laki-laki cenderung lebih banyak mengalami gangguan kognitif dibandingkan perempuan. Demikian pula Syafrita dkk mendapatkan baik laki-laki dan perempuan sama banyaknya mengalami gangguan kognitif. ${ }^{3}$

Suatu penelitian metaanalisis yang melakukan evaluasi hubungan antara kadar CRP dan gangguan fungsi kognitif menemukan bahwa subjek lakilaki usia tua memiliki kadar CRP yang lebih tinggi dibandingkan perempuan dengan usia yang sama. Penelitian lain mengemukakan bahwa laki-laki lebih mudah menurunkan efek inflamasi dibandingkan perempuan, dengan ditemukannya penurunan kadar
CRP 12\% pada laki-laki dibanding perempuan dalam periode 1 tahun. Oleh karena itu, jenis kelamin menjadi variabel penting dalam penelitian antara hubungan inflamasi dan kognisi. Secara epidemiologi, laki-laki juga lebih berpeluang mengalami penyakit kardiovaskuler dan laki-laki usia pertengahan lebih berisiko mendapat gangguan kognitif. ${ }^{6-7}$

Analisis gangguan kognitif pada penelitian kami cenderung terjadi pada tingkat pendidikan yang lebih tinggi, yaitu lebih dari 12 tahun. Zulkifly dkk menyatakan bahwa tingkat pendidikan yang lebih tinggi cenderung tidak mengalami gangguan kognitif pascastroke, dikarenakan mempunyai kapasitas cadangan otak yang lebih besar untuk mengimbangi kerusakan otak. ${ }^{8}$ Syafrita dkk menyatakan tingkat pendidikan lebih rendah $<12$ tahun juga lebih mempunyai risiko gangguan kognitif. ${ }^{3}$

Penelitian ini mendapatkan hasil yang berbeda, bahwa subjek berpendidikan lebih tinggi juga memiliki faktor risiko lain, baik dari faktor usia, riwayat klinis seperti hipertensi, diabetes melitus (DM), dislipidemia, dan merokok yang turut memengaruhi fungsi kognitif. Selain tingkat pendidikan, kompleksitas 
pekerjaan, aktivitas fisik sehari-hari, dan status sosio ekonomi juga memengaruhi kadar CRP dan memengaruhi fungsi kognitif. ${ }^{8}$

Faktor risiko vaskuler seperti gaya hidup, merokok, dan status gizi overweight secara langsung meningkatkan CRP. ${ }^{6}$ Namun penelitian ini tidak mendapatkan hubungan yang bermakna antara kebiasaan merokok dan status IMT dengan fungsi kognitif. Hal ini sesuai dengan penelitian yang dilakukan oleh Nys dkk yang melakukan penelitian pada subjek dengan stroke fase akut, bahwa riwayat merokok lebih dari 5 tahun tidak mempunyai hubungan yang bermakna terhadap fungsi kognitif. ${ }^{7}$

Penelitian ini juga tidak mendapatkan hubungan yang bermakna antara karakteristik infark (letak, jumlah, dan sisi lesi infark) dengan status kognitif. Lokasi lesi subkortikal dalam penelitian ini lebih banyak daripada lesi kortikal. Pada penelitian terdahulu, dikatakan bahwa sitokin pro-inflamasi seperti IL6, IL10, TNF, dan hs-CRP berhubungan dengan stroke. Adanya daerah iskemik akan mengaktivasi sel imun untuk mengeluarkan sitokin proinflamasi. ${ }^{9}$ Penelitian Syafrita dkk yang menghubungkan kadar CRP dengan subtipe stroke, terdapat hubungan yang bermakna antara tingginya kadar hs-CRP dengan subtipe total anterior circulation infarct $(\mathrm{TACI}){ }^{3}$

Saczynski dkk menyatakan volume lesi berhubungan bermakna dengan kadar CRP dan berperan penting pada progresivitas kerusakan jaringan serebral yang menyebabkan gangguan fungsi kognititf. Semakin luas kerusakan lesi dari infark akan diikuti peningkatan kadar hs-CRP. ${ }^{10}$ Ormstaad dkk menyatakan bahwa lokasi stroke, volume, dan jumlah lesi merupakan faktor penting terjadinya penurunan fungsi kognitif pascastroke. ${ }^{11}$ Namun penelitian ini tidak dilakukan penghitungan volume lesi. Selain itu, waktu pemeriksaan CT scan kepala juga tidak sama pada subjek, sehingga menjadi bias tidak seragam terjadinya stroke dan waktu dilakukannya pemeriksaan CT scan kepala.

Pada penelitian ini, ranah fungsi kognitifyang terganggu pada hari ke-7 awitan berturut-turut adalah fungsi eksekutif, memori, atensi, visuokonstruksi, dan fungsi bahasa. Hasil ini sama dengan Nys dkk bahwa fungsi eksekutif dan visuokontruksi yang paling banyak terganggu pada subjek pascastroke fase akut dalam 3 minggu pertama. ${ }^{7}$ Syafrita dkk menemukan gangguan kognitif 3 bulan pascastroke iskemik, berupa fungsi memori $(66,7 \%)$, abstraksi $(66,1 \%)$, dan atensi (50\%). Namun setelah dihubungkan dengan kadar hs-CRP pada fase akut, ditemukan perbedaan yang bermakna antara kelompok dengan kadar hs-CRP tinggi $(>10 \mathrm{mg} / \mathrm{L})$ dengan kelompok normal $(\leq 10 \mathrm{mg} / \mathrm{L})$, untuk ranah visuospasial $(\mathrm{p}=0,002)$, bahasa $(\mathrm{p}=0,047)$, dan orientasi $(\mathrm{p}=0,047) .{ }^{3}$ Gangguan memori bukanlah bentuk gejala awal tersering gangguan kognitif pascastroke, seperti pada Alzeimer, namun yang paling sering ditemukan adalah melambatnya proses berpikir, kesulitan untuk berkosentrasi, dan sulit mengorganisasikan suatu pekerjaan yang akan dilaksanakan (fungsi eksekutif). ${ }^{8}$

Subjek penelitian ini mayoritas mengalami hipertensi, dibanding DM dan dislipidemia. Berdasarkan patofisiologi, masih menjadi perdebatan CRP sebagai faktor risiko vaskuler yang berdiri sendiri atau lebih kepada aterosklerosis yang mendasarinya. Studi review oleh Feinkohl dkk menyatakan bahwa faktor vaskuler dan metabolik mempunyai risiko potensial terjadinya gangguan fungsi kognitif, yang saling berhubungan satu sama lain dengan efek berbagai patofisiologi yang berbeda. ${ }^{12}$

Ge dkk, menyatakan tidak ada perbedaan yang signifikan dalam frekuensi diabetes tipe 2, hipertensi, atau hiperlipidemia antar kelompok terhadap fungsi kognitif. Di antara penyakit-penyakit ini, diabetes tipe 2 telah terbukti berdampak negatif terhadap fungsi kognitif. Seiring berkembangnya sindrom metabolik, diabetes berdampingan dengan hipertensi, hiperlipidemia, dan obesitas, yang mengarah ke kondisi inflamasi yang akhirnya merusak kognitif. ${ }^{13}$ Adapun penelitian Umegaki dkk terhadap subjek diabetes tipe 2 dengan hipertensi berpengaruh terhadap gangguan kognitif dan demensia. ${ }^{14}$ Van Harten dkk melaporkan gangguan beberapa ranah fungsi kognitif pada pasien diabetes tipe 2, sementara pasien hipertensi hanya ranah memori saja 
yang terganggu. ${ }^{15} \mathrm{Ge}$ dkk mengemukakan bahwa inter-relasi antara risiko hipertensi dan kadar serum CRP pada hipokampus kiri dapat disertai atau tanpa gangguan kognitif. ${ }^{13}$

Pasien non-diabetes dan non-dislipidemia pada penelitian ini juga memiliki faktor risiko lain untuk gangguan fungsi kognitif, seperti hipertensi, usia tua, tingkat pendidikan rendah, serta distribusi dan lokasi lesi yang dapat memperburuk luaran fungsi kognitif. Faktor lain yang berperan namun belum dapat diperhitungkan pada penelitian ini, seperti IL6, ATP, ICAM, dan VCAM. Demikian pula pengaruh genetik Apo E $\varepsilon 473$ yang memulai dan mempercepat akumulasi $\mathrm{A} \beta$, agregasi, dan pengendapannya di otak, sehingga mempercepat terjadinya demensia. Hasil yang bertolak belakang pada penelitian dengan lebih banyak subjek tanpa diabetes dan tanpa dislipidemia yang lebih banyak mengalami gangguan kognitif kemungkinan dikaitkan dengan proporsi yang tidak seimbang antara subjek dengan non-DM dan nondislipidemia yang jauh lebih besar proporsinya dibandingkan subjek DM dan dislipidemia ${ }^{12-13}$

Pemberian terapi antiinflamasi seperti aspirin dan statin terbukti signifikan menurunkan kadar CRP dalam sirkulasi pada penyakit kardiovaskuler. Juga aktivitas fisik serta perbaikan gaya hidup dapat menurunkan kadar CRP dan memengaruhi fungsi kognitif, yang sayangnya aktivitas fisik tidak dimasukkan di dalam variabel penelitian ini. Faktor risiko vaskuler tidak berdiri sendiri tetapi juga memiliki faktor risiko lain untuk gangguan kognitif, seperti usia tua, tingkat pendidikan, dan volume lesi yang dapat memperburuk keluaran fungsi kognitif. ${ }^{13}$

Dari penelitian ini didapatkan pada sebagian besar subjek memiliki rerata kadar hs-CRP yang meningkat pada hari ke-3 dan hari ke-7 setelah awitan. Perbedaan tersebut bisa diakibatkan adanya faktor-faktor lain yang tidak dianalisis dalam penelitian, misalnya diet yang dilakukan oleh subjek. Meskipun rerata perubahan kadar hs-CRP dari hari ke-3 dan hari ke-7 setelah awitan terjadi penurunan, tetapi rerata tersebut masih tetap di atas kadar nilai normal. Peningkatan kadar hs-CRP ini sesuai dengan hipotesis awal, bahwa rerata kadar hs-CRP pada pasien stroke iskemik akut lebih tinggi dari normal. Secara proporsional subjek dengan perubahan kadar hs-CRP yang meningkat dari hari ke-3 dan hari ke-7 setelah awitan cenderung mengalami gangguan fungsi kognitif dibandingkan dengan subjek yang mengalami penurunan kadar hs-CRP. Juga terdapat hubungan yang bermakna antara perubahan kadar hsCRP hari ke-3 dan hari ke-7 setelah awitan dengan fungsi kognitif.

Pada penelitian Syafrita, pemeriksaan hsCRP dilakukan 1 kali yaitu pada awitan hari ke-3, dan meskipun sebagian besar kasus yaitu 13 kasus mempunyai kadar hs-CRP normal. Namun saat dihubungkan antara kadar hs-CRP dengan fungsi kognitif setelah 3 bulan awitan terdapat hubungan bermakna antara kadar hs-CRP dengan gangguan beberapa ranah kognitif. ${ }^{3}$ Studi sistematik review dan meta analisis oleh Kuo dkk juga menyimpulkan bahwa kadar CRP yang meningkat berhubungan dengan terjadinya penurunan fungsi kognitif dan risiko terjadinya demensia.

Hal ini dikarenakan CRP akan mengaktivasi sistem komplemen, yang menyebabkan kaskade sistem imun dan terjadinya neurodegenerasi. ${ }^{16}$ Mekanisme inflamasi juga dipengaruhi oleh risiko penyakit sindrom metabolik, yang menyebabkan injury pada makroangiopati dan mikroangiopati, diantaranya diabetes, hipertensi, dan dislipidemia. CRP telah terbukti menjadi bagian aktif dalam proses aterosklerosis dalam penelitian hewan terbaru. Penelitian yang memeriksa hubungan antara CRP dan stroke, meskipun ada, relatif jarang dan belum secara sistematis dianalisis. ${ }^{12,16}$ Konsentrasi CRP yang lebih tinggi juga ditemukan pada penderita depresi, namun masih terbatas pada sampel dengan klinis tertentu dan gagal mengendalikan faktor perancu. ${ }^{16}$

Oleh karena itu, pencantuman pengukuran CRP menjadi salah satu strategi penilaian penderita stroke, termasuk disarankan oleh American Heart Association, karena mempunyai sensitivitas, presisi, dan akurasi, yang tinggi. ${ }^{17}$ Pengukuran hs-CRP harus dilakukan dalam keadaan matabolisme stabil tanpa disertai peradangan atau infeksi yang jelas. Sampai saat ini, masih belum ada konsensus pemeriksaan rutin 
konsentrasi CRP untuk mendeteksi atau memprediksi gangguan kognitif atau depresi. Penelitian Di Napoli dkk mendapatkan cut off point untuk kadar CRP sebesar $1,5 \mathrm{mg} / \mathrm{dL}$ dengan rerata perawatan 8-14 hari, lebih spesifik dan sensitif menentukan luaran dalam waktu 1 tahun. ${ }^{17}$

Adapun Wersching dkk menyatakan rerata kadar hs-CRP pada 447 orang sehat dari SEARCH Health Study, dengan rerata usia 63 tahun, kadar hs-CRP sebesar $0,12(0,07-0,248) \mathrm{mg} / \mathrm{dl}$ berhubungan dengan penurunan fungsi kognitif yang memengaruhi fungsi kognitif. ${ }^{6}$ Paparan jangka panjang terhadap faktor risiko vaskular cenderung berperan dalam etiologi penurunan kognitif yang dapat didukung dengan mengukur ketebalan tunika intima-media dinding pembuluh karotis. ${ }^{18}$ Adanya penebalan di tunika tersebut merupakan indikasi langsung deposisi lipid pada dinding pembuluh darah dan dapat digunakan sebagai penanda pengganti untuk penyakit aterosklerosis, indeks prediktif untuk penyakit kardiovaskuler klinis, dan untuk menentukan keberhasilan intervensi. ${ }^{18}$

Keterbatasan penelitian ini dapat disebabkan karena beberapa hal, antara lain tidak diperhitungkannya lama subjek menderita riwayat klinis yang diderita serta hal-hal yang berpengaruh terhadap fungsi kognitif, seperti viskositas darah, kompleksitas pekerjaan, dan faktor genetik. Demikian pula rentang pengukuran hs-CRP pertama dan kedua terlalu pendek (hanya 5 hari), tidak diukurnya volume infark serebral dan fungsi hati, tidak adanya data awal kognitif subjek, serta jumlah sampel yang sangat sedikit. Namun penelitian ini berusaha menganalisis pengaruh berbagai faktor resiko vaskuler terhadap munculnya gangguan fungsi kognitif pada pascastroke iskemik yang belum dinilai pada penelitian Syafrita dikarenakan keterbatasan penelitian. $^{3}$

\section{KESIMPULAN}

Didapatkan hubungan yang bermakna antara peningkatan kadar hs-CRP pada hari ke-7 dari kadar hari ke-3 dengan fungsi kognitif pasien stroke iskemik akut. Tidak terdapat hubungan yang bermakna antara faktor risiko lainnya dengan fungsi kognitif pada pasien pascastroke iskemik fase akut.

\section{DAFTAR PUSTAKA}

1. Noble JM, Manly JJ, Schupf N, Tang MX, Mayeux R, Luchsinger JA. Association of C-reactive protein with cognitive impairment. Archneurol. 2010;67(1):87-92.

2. Danovska M, Peychinska D. Post-stroke cognitive impairment-phenomenology and prognostic factors. J IMAB. 2012;18(3):290-5.

3. Syafrita Y, Amir D, Decroli E, Susanti R. Hubungan kadar hs-CRP dan fungsi kognitif pascastroke iskemik. Neurona. 2013;30(3):173-8.

4. Napoli MD, Papa F, Bocola V. C-reactive protein in ischemic stroke an independent prognostic factor. Stroke. 2001;32(4):917-24.

5. Godefroy O, Fickl A, Roussel M, Auribault C, Bugnicourt JM, Lamy C, dkk. Is the montreal cognitive assessment superior to the mini-mental state examination to detect poststroke cognitive impairment?: a study with neuropsychological evaluation. Stroke. 2011;42(6):1712-6.

6. Wersching H, Duning T, Lohmann H, Mohammadi S, Stehling C, Fobker M, dkk. Serum CRP is linked to cerebral microstructural integrity and cognitive function. AAN Neurol. 2010;74(10):1022-8.

7. Nys G, Van Zandvoort M, De KortP, Jansen B, De Haan E, Kappelle L. Cognitive disorders in acute stroke: prevalence and clinical determinants. Cerebrovasc Dis. 2007;23(5-6):408-16.

8. Zulkifli M, Ghazali S, din N, Singh DK, Subramaniam P. A review of risk factor cognitive impairment in stroke survivor. Hindawi the scientific World J. 2016;2016:3456943.

9. Amantea D, Nappi G, Bernardi G, Bagetta G, dan Corasaniti MT. Minireview: post-ischemic brain damage: pathophysiology and role of inflammatory mediators. FEBS J. 2008;276(1):13-26.

10. Saczynski JS, Sigurdsson S, Jonsdottir MK, Eiriksdottir G, Jonsson PV, Garcia ME, dkk. Cerebral infarcts and cognitive performance importance of location and number of infarcts. Stroke. 2009;40(3):677-82.

11. Ormstad H, Aass HC, Lund-Sorensen N, Amthor FK, Sandvik L. Serum level cytokines CRP in acute ischemic stroke and their relationship to stroke lateralisation, type and infarct volume. $\mathrm{J}$ neurol. 2010;258(4):677-85.

12. Feinkohl I, Price JF, Strachan MJ, Frier BM. The impact of diabetes on cognitive decline potential vascular, metabolic and phychosocial risk factor. Alzheimer Res Ther. 2015;7(1):46.

13. Ge X, Xu XY, Feng CH, Wang Y, Li YL, Feng B. Relationship among serum CRP, RAGE, metabolic dysfunction and cognitive impairments. BMC Neurol. 2013;13(1):110. 
14. Umegaki H. Type 2 diabetes as a risk factor for cognitive impairment: current insights. Clin Interv Aging. 2014;9:1011-9.

15. Van-Harten B, Oosterman J, Muslimovic D, Van-Loon BJ, Scheltens P, Weinstein HC. Cognitive impairment and MRI correlates in the elderly patients with type 2 diabetes mellitus. Age Ageing. 2007;36(2):164-70.

16. Kuo HK, Yen CJ, Chang CH, Kuo CK, Chen JH, Sorond F. Relation of CRP to stroke, cognitive disorder and depression in the general population: systematic review and metanalysis. Lancet Neurol. 2005;4(6):371-80.
17. Di-Napoli M, Schwaninger M, Cappelli R, Ceccarelli E, Di-Gianfilippo G, Donati C, dkk. Evaluation of $\mathrm{C}$-reactive protein measurement for assessing the risk and prognosis in ischemic stroke. J AHA. 2005;36(6):1316-29.

18. Arntzen KA, Schirmer H, Johnsen SH, Wilsgaard T, Mathiesen EB. Carotid atherosclerosis predicts lower cognitive test results: a 7-year follow-up study of 4,371 stroke-free subjects- the Tromso study. Cerebrovasc Dis. 2012;33(2):159-65. 